\title{
ACESSO E EXPANSÃO DE CURSOS DE GRADUAÇ̃̃O DE ALTA QUALIDADE NO BRASIL: OUTROS INDICADORES DE QUALIDADE PARA A EDUCAC̦ÃO SUPERIOR
}

\author{
José Vieira de Sousa \\ Universidade de Brasília (UnB), Brasília - DF, Brasil \\ Otilia Maria L. B. Seiffert* \\ Universidade Federal de São Paulo (Unifesp), São Paulo - SP, Brasil \\ Ivanildo Ramos Fernandes "** \\ Universidade Candido Mendes (Ucam), Rio de Janeiro - RJ, Brasil
}

RESUMO: $\mathrm{O}$ artigo apresenta resultados parciais de pesquisa com foco na expansão e no acesso a cursos de graduação de alta qualidade avaliados pelo Sistema Nacional de Avaliação da Educação Superior (Sinaes). Discute aspectos que favorecem a compreensão da avaliação da qualidade da educação superior e do debate sobre o Estado avaliador e o Estado regulador. Focaliza as bases epistemológicas e a disputa pela concepção de qualidade no Sinaes capazes de provocar alterações no caráter formativo-emancipatório atribuído à avaliação. A análise de quatro cursos com maior expansão e de alta qualidade, reiterada nos três ciclos avaliativos (2004-2012), evidencia que a ampliação desses cursos não se dá no mesmo ritmo da que ocorre de forma geral. A reflexão mostra também que o Enade se consolida como métrica eficaz de qualidade, mas requer associação a outros indicadores.

Palavras-chave: Educação superior. Avaliação de qualidade. Acesso. Expansão. Enade.

http://dx.doi.org/10.1590/0102-4698161997

" Licenciado em Pedagogia e Letras, Mestre em Educação e Doutor em Sociologia pela Universidade de Brasília/UnB. Professor Associado da UnB. Líder do Grupo de Estudos de Políticas de Avaliação da Educação Superior (Gepaes), da Rede Universitas/Br e membro do Observatório de Pesquisa das Políticas de Avaliação da Educação Superior (POW1). E-mail: < sovieira1@gmail.com>.

“" Doutora em Psicologia da Educação pela PUC-SP, Mestre em Educação pela University of Texas at Austin, Bacharelado em Psicologia pela University of Texas at Austin. Professora-Adjunta aposentada colaboradora da Universidade Federal de São Paulo, membro da Rede Universitas/Br e do Observatório de Pesquisa das Políticas de Avaliação da Educação Superior (POW1). Email: < otiliaseiffert@gmail.com>.

"**Especialista em Políticas Públicas e Avaliação da Educação Superior pela Universidade Federal da Integração Latino-Americana (Unila/PR). Diretor de Regulação e Avaliação da Universidade Candido Mendes (Ucam), membro do Grupo de Estudos de Políticas de Avaliação da Educação Superior (GEPAES), da Rede Universitas/Br e do grupo Observatório e Pesquisa das Políticas de Avaliação da Educação Superior (POW1) e do núcleo de pesquisas Observatório Universitário/RJ. E-mail: < ramos.ives@gmail.com>. 


\section{EXPANSION AND ACCESS TO HIGH QUALITY UNDERGRADUATE COURSES IN BRAZIL: OTHER QUALITY INDICATORS FOR HIGHER EDUCATION}

ABSTRACT: The article presents partial results of research focused on the expansion and access to high quality undergraduate courses according to Sinaes. It discusses aspects that favor the understanding of the evaluation of quality of higher education and the debate concerning the evaluative state and the regulatory state. It approaches the epistemological basis and the dispute for the conception of quality in the Sinaes that are able to change the formative-emancipatory evaluation of the exam. The analysis of four courses with greater expansion, and the repeated high quality in the three evaluation cycles (2004-2012) indicates that the expansion of high quality courses does not occur the rhythm of the overall expansion. The reflection also demonstrates that the Enade has consolidated itself as an efficient quality metric but its association with other indicators is required. Keywords: Higher education. Quality assessment. Access. Enade. Expansion.

\section{INTRODUĈ̣̃O}

Este artigo apresenta resultados parciais de investigação iniciada em 2012, realizada por pesquisadores associados à Rede Universitas/Br e ao GT 11 - Política de Educação Superior -, da Associação Nacional de Pós-Graduação e Pesquisa em Educação/ANPEd. A pesquisa é parte do projeto integrado do Observatório da Educação (Obeduc) "Políticas da Expansão da Educação Superior no Brasil".

O objetivo do trabalho é analisar os elementos que concorrem para a compreensão dos critérios oficiais que vêm orientando a avaliação de qualidade e a expansão da educação superior brasileira no âmbito do Sistema Nacional de Avaliação da Educação Superior (Sinaes), aprovado pela Lei no 10.861/2004 (BRASIL, 2004). A discussão aborda o processo de avaliação e regulação das Instituições de Educação Superior (IES) do Sistema Federal de Ensino (SFE). Em termos mais específicos, o texto busca compreender os elementos que mais se destacam na concepção de qualidade dos cursos de graduação que obtiveram conceitos 4 e 5 no Exame Nacional de Desempenho dos Estudantes (Enade), um dos componentes do sistema. Para a presente pesquisa, foram selecionados os cursos de Administração, Enfermagem, Engenharia Civil e Pedagogia, sobretudo por eles terem apresentado maior expansão após a implantação do Sinaes e também por terem passado por ciclos avaliativos entre 2004 e 2012.

A opção por focalizar os resultados do Enade nos referidos cursos justifica-se pelo fato de que, de todas as avaliações do Sinaes, 
essa é a única cujo conceito do exame produziu dados públicos em série. Além disso, seus resultados têm sido adotados pelo Ministério da Educação (MEC) para orientar a expansão de cursos e condução de políticas públicas para a educação superior no país. Registre-se que a decisão de avaliar a qualidade desses cursos a partir dos resultados do Enade reflete apenas uma opção metodológica, e não a chancela do argumento de que existe protagonismo do Enade na política de avaliação de qualidade.

Em virtude de o Sinaes ter sido proposto como indutor da qualidade das IES, dos cursos e da formação dos estudantes, este artigo sugere uma reflexão que parte das seguintes perguntas:

(i) qual fotografia podemos fazer do processo de expansão da educação superior e de sua relação com os resultados do Sinaes/Enade?

(ii) os resultados das avaliações fomentaram a expansão de cursos de qualidade?

(iii) a qualidade tem orientado a expansão desse nível educacional, considerando-se os cursos avaliados, no recorte temporal eleito para o estudo apresentado?

Essas perguntas foram formuladas levando-se em conta que a proposta do Sinaes foi estruturada sobre um modelo de avaliação formativa e emancipatória, cuja execução envolve processos avaliativos e regulatórios, que podem ocorrer de maneira dissociada ou concomitante, sem prejuízo do caráter sistêmico dos resultados.

De acordo com a Lei no $10.861 / 2004$, o Sinaes é composto pelas seguintes modalidades: (i) Avaliação das Instituições da Educação Superior (Avalies), que busca identificar o perfil e o significado da atuação das IES, analisando em dez diferentes dimensões atividades, cursos, programas, projetos e setores, o que implica autoavaliação e avaliação externa (art. $3^{\circ}$ ); (ii) Avaliação dos Cursos de Graduação (ACG), a qual objetiva "identificar as condições de ensino oferecidas aos estudantes, em especial as relativas ao perfil do corpo docente, às instalações físicas e à organização didático-pedagógica" (art. $4^{\circ}$ ); (iii) Exame Nacional de Desempenho dos Estudantes (Enade), com periodicidade trienal de aplicação em cada curso, destinado a aferir o desempenho dos discentes

[...] em relação aos conteúdos programáticos previstos nas diretrizes curriculares do respectivo curso de graduação, suas habilidades para ajustamento às exigências decorrentes da evolução do conhecimento e suas competências para compreender temas exteriores ao âmbito específico de sua profissão, ligados à realidade brasileira e mundial e a outras áreas do conhecimento (BRASIL, 2004, art. $5^{\circ}, \int 1^{\circ}$ ) 
O percurso metodológico da pesquisa compreendeu, na dimensão qualitativa, revisão bibliográfica e estudo da legislação específica sobre avaliação e documentos de políticas públicas e da regulação do MEC. De acordo com Chizzotti (2006, p. 19), a pesquisa documental é "uma etapa importante para se reunirem os documentos já produzidos e eleger os instrumentos necessários ao estudo de um problema relevante e atual, sem incidir em questões já resolvidas, ou trilhar percursos já realizados". $\mathrm{Na}$ dimensão quantitativa, foram feitas a captação e a análise de: (i) planilhas do Enade fornecidas pela Diretoria de Avaliação da Educação Superior (Daes/ Instituto Nacional de Estudos e Pesquisas Educacionais Anísio Teixeira Inep); (ii) insumos do Conceito Preliminar de Curso (CPC) e do Índice Geral de Curso (IGC), disponíveis no site daquele órgão; (iii) censo da educação superior dos quatro cursos selecionados para estudo; (iv) atos regulatórios desses cursos, publicados pelo MEC, no Diário Oficial da União (DOU), entre 2004 e 2014.

Este artigo está organizado em três seções, além da introdução e das considerações finais. A primeira delas aborda a centralidade assumida pelas lógicas do Estado avaliador e do Estado regulador em relação à educação superior do país, enfatizando sua relação com as políticas definidas para esse nível educacional, tendo a proposta avaliativa do Sinaes como foco. A segunda seção discute as bases epistemológicas do Sinaes e sua dinâmica, com destaque para a disputa em torno da concepção de qualidade expressa nesse sistema. A terceira e última parte apresenta e trata dos dados do Enade dos quatro cursos selecionados, de acordo com a categoria administrativa e a organização acadêmica das IES que os ofertam.

\section{ESTADO AVALIADOR, ESTADO REGULADOR: DINÂMICAS E TENSÕES}

A prática atual demonstra que a análise realizada pelo Estado avaliador, executada pelo Inep e com o suporte da Comissão Nacional de Avaliação da Educação Superior (Conaes), não se efetiva como processo autônomo, formativo e emancipatório, visando à melhoria da IES. Caracteriza-se mais como avaliação somativa, com o objetivo de reunir elementos para a tomada de decisões regulatórias. Todavia, Griboski e Fernandes (2012, p. 120) defendem que isso não anula seu potencial formativo, pois “o apego a conceitos clássicos de avaliação, que sustentam muitas das críticas aos indicadores de qualidade, mesmo que preliminares, parece não ajudar na evolução do debate".

Dessa forma, os autores entendem que a avaliação atingiria seu potencial formativo-emancipatório. Formativo, porque a IES 
pode, a partir da avaliação, ajustar condutas, superar fragilidades e potencializar seus pontos fortes; emancipatório, porque, a partir da qualidade detectada ou construída no processo formativo, a IES ganha prestígio perante a sociedade e diminui sua condição de tutelada do Estado regulador, o qual passa a lhe proporcionar mais autonomia. Mudanças positivas também resultam da regulação, ainda que se faça uso do poder de impor o "cumpra-se", à luz dos próprios resultados da avaliação. Isso pode evidenciar uma aliança entre a avaliação e a capacidade de indução e de fiscalização que o Estado tem para fazer valerem suas determinações.

Nesse contexto, o Estado reconhece a força e a credibilidade de que a avaliação goza entre os acadêmicos. Esses, por sua vez, chancelam a força daquele para legitimar os resultados da análise e propor melhorias e o ajuste de condutas. Contudo, tem sido habitual a crítica de que eventual melhoria - ou emancipação - não decorre da vontade dos avaliados, mas de imposição decretada pelas instâncias estatais (NEAVE, 1998).

O mesmo autor critica o fato de o Estado avaliador ter criado uma homogeneidade avaliativa que não se distancia do modelo de controle adotado pelo Estado em relação às atividades das IES antes da década de 1990. Para ele, embora a entrada em cena da avaliação tenha gerado expectativa de emancipação, os critérios do método anterior têm assumido as mesmas finalidades daqueles de natureza legal e regulatória. Essas críticas permitem inferir que o Estado avaliador e o Estado regulador são duas faces da mesma moeda, ainda que o autor não deixe claro se a ambivalência de funções do Estado causaria prejuízo por conta do controle ou do tipo de qualidade produzida nos cursos de nível superior.

A consequência mais direta é que, de um lado, as IES parecem aspirar a uma menor interferência estatal e, do outro, às vezes a sociedade emite sinais de que deseja esse controle. Segundo Dias Sobrinho (2002), é sob o argumento de que a sociedade quer saber o que ocorre dentro das instituições que se exige do Estado a formulação e o estabelecimento de políticas, metas e objetivos para elas e cujo cumprimento será verificado mediante avaliações in loco. Nesse cenário, Peixoto et al. (2016) sustentam que não é apenas a qualidade das atividades acadêmicas que está em cena, mas a disputa pela chancela estatal dela.

Diplomas universitários agregam capital econômico a seus portadores, de modo que a chancela estatal atribuída aos cursos que passam pelo crivo do Sinaes seria resultado dessa demanda que a sociedade reclama do Estado. Assim, e se também considerarmos a 
percepção de Sousa e Fernandes (2016), poderemos entender que o discurso de que a avaliação pode garantir emancipação é, ao mesmo tempo, um ideal e um dilema. No primeiro caso, porque pode levar a uma maior emancipação das IES, uma vez que se fala do controle estatal das atividades acadêmicas; no segundo caso, porque pode evocar maior presença do Estado, já que se requer dele a defesa dos interesses das IES e o controle da qualidade.

Recorrendo a Lowi (2009), pode-se afirmar que o modelo de qualidade em vigor nos aparelhos do Estado privilegia as arenas de maior expressão da sociedade e do mercado. Isso desautoriza apontar-se que existe um "conceito oficial de qualidade", sendo mais recomendável falar de conceito praticado no Estado, o qual não seria exatamente um conceito estatal. Foucault (1979) alerta que devemos mudar o método com que habitualmente analisamos a ação do Estado, de cima para baixo (método descendente), no qual as imposições descem do Estado à sociedade. Para ele, se queremos saber o que se passa no Estado ou como pensa ou age o governo, devemos adotar o método ascendente, "partir dos mecanismos infinitesimais" (FOUCAULT, 1979, p. 182), para captar a ação estatal nas extremidades, nas últimas ramificações. Assim, a ação do Estado denota assimetria e se irradia de baixo para cima, dando suporte às instâncias de autoridade, aos poderes instituídos do Estado.

Nessa perspectiva, tanto o desvirtuamento das bases epistemológicas na execução do Sinaes quanto seu desuso, como ressaltam Sousa e Fernandes (2015), podem colocar os pesquisadores em uma armadilha metodológica, segundo a qual toda dinâmica seria negativa. A nosso ver, o que se chama de conceito oficial de qualidade no âmbito do Sinaes, com o protagonismo do Enade, do CPC e do IGC, nada mais é do que a realidade operando sobre os referenciais legais, o que significa dizer que a qualidade oficial resulta da avaliação efetivamente praticada, a despeito do que foi previsto na lei. É a infraestrutura exercendo sua força sobre a superestrutura; a práxis determinando a teoria e a norma e, assim, criando nova práxis (MARX, 1985).

\section{A DINÂMICA EPISTEMOLÓGICA E A DISPUTA PELA CONCEPC̣ÃO DE QUALIDADE NO SINAES}

O Sinaes representa um contraponto à política educacional que vinha sendo adotada, em particular o extinto Exame Nacional de Cursos, conhecido como "Provão", que vigorou entre 1996 e 2003. 
Com sua criação, suas bases epistemológicas e processos avaliativos favoreceram uma proposta de mudança qualitativa e emancipatória relevante para a IES.

Em 2007, a Portaria Normativa n ${ }^{\circ} 40$ propiciou a implementação de indicadores de qualidade da educação superior, calculados pelo Inep, com base nos resultados do Enade e em outros insumos constantes das bases de dados do MEC. Para tanto, em 2008, foram criados o Conceito Preliminar de Curso (CPC) e o Índice Geral de Cursos Avaliados da Instituição (IGC), que, assim como a Avalies, a ACG e o Enade, adotam a escala de cinco níveis, em que os iguais ou superiores a três indicam qualidade satisfatória (BRASIL, 2007b, 2008a, 2008b). No que tange à política regulatória, têm sido privilegiados os resultados do Enade e os indicadores de qualidade (CPC e IGC). Isso denota que o referido exame constitui relevante peça de instrução na execução de políticas para a educação superior e para a regulação das IES e de seus cursos.

É importante registrar que até 2007 o conceito Enade correspondia à "média ponderada da nota [...] dos concluintes no componente específico, da nota [...] dos ingressantes no componente específico e da nota [...] em formação geral (concluintes e ingressantes), considerando-se, respectivamente, os pesos 60\%, 15\% e 25\%" (INEP, 2007 , p. 5). Assim, $75 \%$ da nota final se referiam à parte do componente específico (CE), e 25\%, à formação geral (FG). Todavia, "a partir de 2008, o conceito Enade passou a considerar em seu cômputo apenas o desempenho dos alunos concluintes" (INEP, 2010, p. 1). Entretanto, os pesos finais de $\mathrm{CE}$ e FG permaneceram inalterados.

Para pesquisar o Sinaes, é preciso levar em conta a "polissemia e a complexidade do conceito de qualidade", conforme enfatiza Sousa (2009, p. 243). A qualidade não só é um conceito polissêmico, como é um conceito em disputa pelos diversos atores ou grupos de atores, que, direta ou indiretamente, manifestam interesse pela educação superior, interferindo em suas políticas e nas agendas dos órgãos públicos. Analisar a avaliação como política pública requer observar as arenas de poder que impõem suas inclinações e seus partidarismos, tanto na política quanto nas instâncias decisórias que a formulam e na burocracia que a executa (LOWI, 2009). Essas arenas expressam as relações dialéticas e suas contradições, fazendo com que a totalidade do Sinaes seja perceptível a partir das diversas forças que o modificam e que agregam novos significados para seus critérios. Certamente, os elementos originais que constituem o sistema ainda estão em vigor, mas novas concepções e percepções de qualidade foram a ele adicionadas. Para efeitos regulatórios, talvez seja suficiente sua 
avaliação pelos critérios do Sinaes, mas, como ela atende a múltiplos fins, é um equívoco examiná-la no âmbito da educação superior apenas à luz das normas, dos instrumentos.

Para Tavares, Rothen e Santana (2015, p. 268), “qualidade é [conceito] polissêmico, havendo diversos significados para esse juízo de valor, que variam conforme o contexto sociopolítico e cultural, dependendo também das concepções do que seja o ato educativo, sua organização e função social". Na mesma linha de raciocínio, Tavares, Oliveira e Seiffert (2011, p. 255) defendem que o CPC e o IGC alteram a concepção original do Sinaes e que as políticas de avaliação nas últimas "duas décadas mostram tendências e conflitos diversos que envolvem as esferas pública e privada".

Os embates em torno da noção de qualidade ocorrem entre as instâncias do próprio Estado, que se fragmentam na disputa individual por espaço, legitimidade e poder. Nesse caso, podemos citar como arenas singulares o Inep, a Conaes, a Secretaria de Educação Superior (Sesu) do MEC, a Secretaria de Regulação da Educação Superior (Seres) do MEC, o Conselho Nacional de Educação (CNE) e a Coordenação de Aperfeiçoamento de Pessoal de Nível Superior Capes. Do lado da academia, cada entidade de representação das IES, mantenedores, docentes, discentes e técnico-administrativos constituem uma arena própria.

Os segmentos público e privado também são espaços em disputa não só pela concepção de qualidade, mas como também pela de educação superior como bem público gratuito ou por sua desvinculação do Estado. Entre os que criticam as universidades públicas, Nunes (2012, p. 39-40) enfatiza que, no Brasil, elas se caracterizam como um "componente, privadíssimo [...] um privilégio tributário para um conjunto restrito de famílias, correspondendo a $25,8 \%$ do total das matrículas superiores [e que] as universidades estatais são entes de governo, não são entes públicos".

Em outra direção, Dias Sobrinho (2013, p. 107) defende que "a educação é um bem público, imprescindível e insubstituível, direito de todos e dever do Estado". Cabe a esse último criar e oferecer condições efetivas para que isso se realize com a amplitude, a qualidade e a sustentabilidade necessárias e adequadas. Em consequência, seja a educação considerada bem público, seja a avaliação tida como compromisso público, já não se sustenta mais a defesa de que ao Estado caberiam o monopólio da oferta da educação superior e sua oferta com qualidade. É um dever que atinge todos, conforme mostra o artigo 209 da Constituição Federal de 1988 (BRASIL, 1988). 
A institucionalização do Sinaes sintetizou as tendências de algumas arenas que já conflitavam com as percepções de qualidade da Comissão Especial de Avaliação (CEA, 2003). Nunes (2015) menciona que, na Medida Provisória n 147/2003 (BRASIL, 2003), a concepção de avaliação já não guardava relação com o relatório da comissão. Mesmo com os ajustes na proposta de lei, subentende-se que, no caminho entre a proposta da CEA e o efetivo texto aprovado, parcela do fundamento teórico foi reinterpretada, voltando-se mais à regulação.

Outra situação que reflete essa tendência é a interpretação da lei e de seus regulamentos feita nas instâncias burocráticas. Foi nessa seara que, com a edição do Decreto n 5.773 de 2006 (BRASIL, 2006), a Consultoria Jurídica (Conjur) do MEC, órgão de assessoria superior do gabinete do Ministro da Educação, revelou uma disputa com o CNE, em relação à concepção de qualidade e aos fins/limites da avaliação. Nessa perspectiva, identifica-se no Parecer CNE/CES no 471/2007 (BRASIL, 2007b) referência ao Parecer no 643/2006 da Conjur/MEC, no qual se enfatizava que, sendo subsídio à regulação, os resultados da avaliação não determinariam a decisão final do regulador. Em momento posterior, por meio do Parecer 37/2010, o CNE entendeu que, sendo referencial, a avaliação "não é determinante". "Isso faculta ao MEC, dentro de seu poder discricionário, regulamentar adicionalmente os demais requisitos que considera relevantes para sua decisão" (BRASIL, 2010, p. 5). O CNE defendia, assim, que a visão do regulador deveria agregar outros meios de convicção ao referencial básico da avaliação, enquanto a Sesu/MEC e a Conjur argumentavam que, por não ser determinante nem referencial básico, a avaliação seria dispensável em algumas situações.

É preciso ter em mente que, desde sua institucionalização, o Sinaes vem passando por alterações significativas, algumas delas tensionando ainda mais o debate em torno do conceito de qualidade na educação superior e daquele referencial teórico que, em 2003, sustentou a proposição de sua lei no Congresso. Nesse contexto e ainda que semanticamente, é essencial que levemos em conta a diferença entre desvirtuamento e desfavorecimento, pois, na reflexão ora proposta, defendemos que as alterações se deram no campo da regulação, e não nas bases epistemológicas da avaliação. A qualidade oficial, segundo os dados divulgados pelo MEC, é uma seleção feita pela regulação, que opta por motivar seus atos a partir do Enade, do CPC e do IGC. Todavia, isso não implica desvirtuamento da política do Sinaes ou de suas bases epistemológicas, nem justifica o argumento de determinados grupos de que há um protagonismo efêmero do 
Enade no âmbito do Sinaes. Na realidade, o que se tem observado é uma crescente centralidade daquele exame no contexto mais amplo da política desse sistema avaliativo.

É verdade que o Enade, o CPC e o IGC protagonizam, desde 2008, o juízo de valor dos reguladores quanto à chancela da qualidade das IES e de seus cursos, mas as demais avaliações do Sinaes (Avalies e ACG) não tiveram sua credibilidade arranhada por essa opção. Também é verdade que a ACG vem sendo dispensada nos casos em que o regulador se dá por satisfeito com os indicadores propiciados pelo Enade, mas também é indiscutível a morosidade processual da Avalies. Isso porque, até o início de 2016, o CNE só deliberara sobre cerca de 40\% dos processos solicitados no ciclo avaliativo 2007-2009.

$\mathrm{Na}$ perspectiva de corroborar a afirmativa feita anteriormente, dados compilados do sistema e-MEC informam que, das 2.124 IES avaliadas pelo Inep até março de 2016, aquelas que obtiveram conceitos entre 3 e 5 chegaram a $96,2 \%$, enquanto, no IGC, $83,2 \%$ estavam nessa faixa, o que revela, em geral, significativos percentuais de conceitos positivos, em escala de 1 a 5 .

GRÁFICO 1 - Distribuição dos atuais conceitos oficiais de qualidade no Sinaes: apenas conceitos positivos, entre 3 e $5-2016$

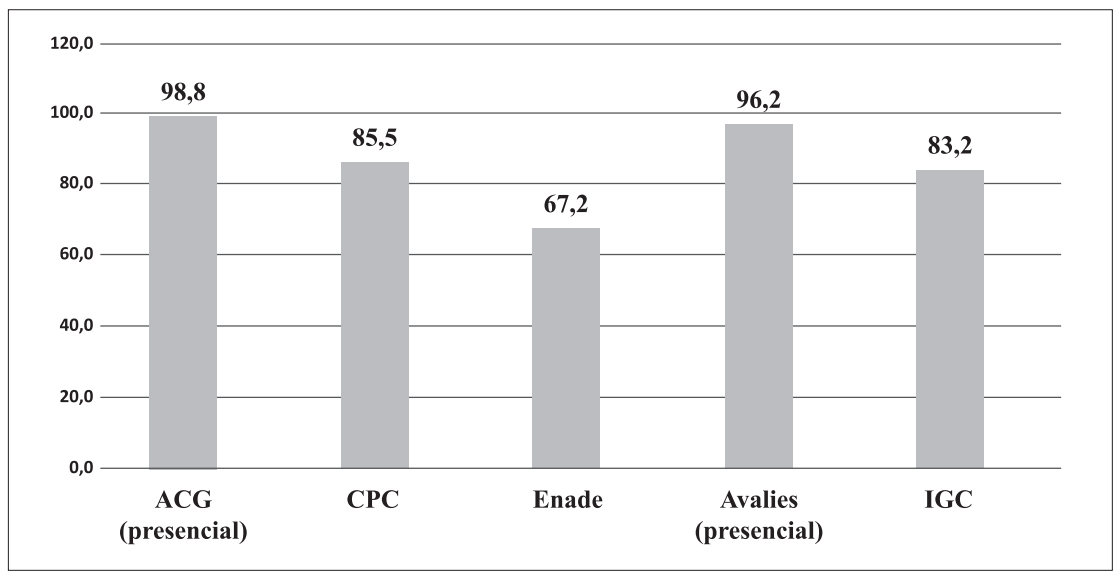

Fonte: Sistema e-MEC ${ }^{1}$, dados coletados em 2/3/2016.

Por sua vez, os dados da ACG coletados em 22 de junho de 2016, no Sistema Integrado de Monitoramento Execução e Controle do Ministério da Educação/Simec-MEC), ${ }^{2}$ que apresenta o número de avaliações realizadas, informam que, entre 2004 e 2015, foram feitas 34.013 avaliações de cursos pelo Inep. Ora, como de acordo com a mesma fonte, o SFE era integrado, no último ano citado, por 2.177 
IES e 31.513 cursos presenciais, considerando-se o total de Avalies e ACG realizadas, não há base empírica para afirmar que tenha havido desvirtuamento da política do Sinaes, posto que o objetivo teleológico da lei é avaliar a qualidade. Os dados mostram que há simetria entre a quantidade de avaliações e a de IES e de cursos.

À luz da expansão da educação superior, as diferentes concepções de qualidade e dos fins desse nível educacional revelam a capacidade de dinâmica do Sinaes para seu ajustamento à realidade das IES em termos da política avaliativa. Indicam ainda que a realidade lhe impõe modificações, entendidas ora como positivas, ora como negativas, a depender do ponto de partida do crítico. Podese dizer que a avaliação não assume apenas as funções de formação e emancipação, como definiram os teóricos da CEA em 2003; aos poucos, ela própria tem se emancipado do controle do Estado. Em outras palavras, a avaliação tem se requalificado em relação à gerência do governo à medida que os "sinais da qualidade", advindos das diversas ferramentas do sistema, apresentam potencial para abrandar esse controle e, com isso, proporcionar autonomia e emancipação às instituições que ofertam educação superior.

Também é importante considerar que a opção de o Estado regulador espelhar a qualidade dos cursos pelo ângulo do Enade e do CPC não determina que haja protagonismo desses no âmbito do Estado avaliador. Com efeito, esses dois conceitos, acrescidos do IGC, configuram o alto relevo da motivação para a busca da qualidade, mas quem poderá afirmar que os demais indicadores dispostos à mesa do regulador, oferecidos por esse modelo de Estado, realmente são desprezados?

Apresentadas essas reflexões, os dados e os argumentos a seguir dispostos refletem a percepção sobre qualidade nos quatro cursos estudados à luz do conceito Enade, sem que se tenha adentrado o mérito de que esse indicador seria o conceito oficial de qualidade, eleito pelo regulador. Para efeitos deste trabalho, ele é apenas a face mais acessível dessa qualidade no momento atual.

\section{RESULTADOS DO ENADE NOS CURSOS DE ADMINISTRAÇÃO, ENGENHARIA CIVIL, ENFERMAGEM E PEDAGOGIA}

Adotou-se como foco inicial de análise desta seção a expansão da educação superior, de modo a se discutir a forma como esse crescimento ocorreu no contexto do Sinaes, mais especificamente à luz dos resultados do Enade obtidos pelos quatro cursos estudados. 
Com efeito, a Lei de Diretrizes e Bases da Educação Nacional/1996 (LDBEN) (BRASIL, 1996) reformula a política educacional e promove relevantes mudanças no sistema de educação brasileiro a partir de seus dois grandes eixos - flexibilidade e avaliação. Estudo realizado pelo Inep em 2005, em parceria com pesquisadores da Rede Universitas/BR, aponta que, no período préLDB, houve pequena expansão da educação superior, que aguardava a sedimentação dos debates e dos embates que direcionariam a lei (RISTOFF; GIOLO, 2006).

A Constituição Federal de 1988 e a referida lei determinaram a obrigatoriedade da avaliação do sistema de educação superior, também expressa no Plano Nacional de Educação (PNE 2001-2010), criado pela Lei $\mathrm{n}^{\circ} 10.172 / 2001$, visando ao fortalecimento de uma cultura avaliativa. Assim, em seu artigo $4^{\circ}$, a última lei mencionada estabeleceu que a União instituiria o Sistema Nacional de Avaliação e os mecanismos para o acompanhamento das metas constantes do PNE (BRASIL, 2001).

O Sinaes se propôs a se diferenciar de outros modelos avaliativos desenvolvidos para aferir qualidade no Brasil até sua implantação. Para Tavares, Oliveira e Seiffert (2011, p. 244-245), essa política avaliativa se constitui em "um sistema integrador, que garante informações e análises da totalidade da educação superior [...] Nesse sistema, um dos grandes desafios é colocar em exercício os processos avaliativos integrados aos processos regulatórios".

Cabe destacar que a proposta do Sinaes se fortaleceu em razão das críticas ao Exame Nacional dos Cursos (ENC), ou "Provão", que, conforme assevera Giolo (2008, p. 852):

(1) Avaliava o resultado final e não o processo de formação realizado no âmbito das IES, com isso deixava de considerar o impacto efetivo que a educação superior realizava em termos de formação de seus alunos; (2) produzia um juízo sobre um curso e/ou sobre uma instituição com base num exame respondido pelos concluintes sem que eles mesmos, enquanto indivíduos, obtivessem os louros ou os prejuízos em função das respostas que forneciam; (3) induzia a um ranque de cursos e instituições com base num único indicador, homogeneizando o sistema, ao passo que a legislação e as diretrizes curriculares nacionais haviam estimulado a diversificação do sistema (em termos de categorias administrativas, organizações acadêmicas, projetos pedagógicos, estruturas de cursos, etc.); e, por fim, (4) estimulava o "o planejamento estratégico perverso" das instituições e cursos no sentido de passarem a concentrar seus esforços apenas nas atividades destinadas a obter uma pontuação satisfatória no indicador aferido pelo MEC (os famosos cursinhos preparatórios), descuidando das demais dimensões acadêmicas (aspas no original).

Superada mais de uma década, desde a aprovação do Sinaes, foram registradas mudanças cruciais na execução do sistema e no 
papel dos distintos indicadores, no processo de avaliação das IES e, consequentemente, na conduta dos reguladores e em seus elementos de convicção, conforme explicitado nas seções anteriores. Tais mudanças ocorreram, sobretudo, por conta das políticas educacionais orientadas pelos organismos econômico-financeiros multilaterais, expressando as seguintes características: expansão; privatização; diversidade; centralização; desequilíbrio regional; ampliação do acesso; desequilíbrio da oferta; ociosidade de vagas; corrida por titulação; e o lento aumento na taxa de escolarização superior, como assinalava Ristoff (2008).

A Tabela 1 ilustra o significativo crescimento registrado entre 2004 e 2013 nos cursos de Engenharia Civil (75\%) e Enfermagem (55,1\%), enquanto os de Administração e Pedagogia tiveram avanços mais discretos, de $28,3 \%$ e $12,2 \%$, respectivamente.

TABELA 1 - Expansão dos cursos de graduação em Administração, Engenharia Civil, Enfermagem e Pedagogia (2004 e 2013)

\begin{tabular}{|c|c|c|c|c|c|c|c|c|c|}
\hline \multirow{3}{*}{$\begin{array}{l}\text { Cursos de } \\
\text { graduação }\end{array}$} & \multicolumn{3}{|c|}{ Dados gerais } & \multicolumn{3}{|c|}{ Rede privada } & \multicolumn{3}{|c|}{ Rede pública } \\
\hline & \multicolumn{2}{|c|}{ Intervalo } & \multirow{2}{*}{$\Delta \%$} & \multicolumn{2}{|c|}{ Intervalo } & \multirow{2}{*}{$\Delta \%$} & \multicolumn{2}{|c|}{ Intervalo } & \multirow{2}{*}{$\Delta \%$} \\
\hline & 2004 & 2013 & & 2004 & 2013 & & 2004 & 2013 & \\
\hline Administração & 1.456 & 2.031 & $28,3 \%$ & 1.296 & 1.734 & $25,3 \%$ & 160 & 297 & $46,1 \%$ \\
\hline $\begin{array}{l}\text { Engenharia } \\
\text { Civil }\end{array}$ & 132 & 528 & $75,0 \%$ & 77 & 401 & $80,8 \%$ & 55 & 127 & $56,7 \%$ \\
\hline Enfermagem & 381 & 849 & $55,1 \%$ & 308 & 680 & $54,7 \%$ & 73 & 169 & $56,8 \%$ \\
\hline Pedagogia & 1.437 & 1.637 & $12,2 \%$ & 780 & 1.026 & $24,0 \%$ & 657 & 611 & $.7,5 \%$ \\
\hline
\end{tabular}

Fonte: Censo da Educação Superior do Inep, 2004 e $2013 .^{3}$

Observa-se que as IES privadas predominaram na oferta dos cursos investigados, ratificando a premissa que tem orientado a construção e a consolidação do campo da educação superior brasileira: a de definição de "políticas que acabaram por configurar uma tendência histórica de restrição da esfera pública e de estímulo à esfera privada" (SOUSA, 2013, p. 5).

No curso de Administração, o aumento total foi de $28,3 \%$ $(2004=1.456$ e $2013=2.031)$. Na rede privada, ele apresentou, nesse período, um crescimento de $25,3 \%$, enquanto na rede pública o percentual foi de $46,1 \%$. Entre as razões que justificam sua supremacia quantitativa sobre os demais cursos está o fato de as organizações 
terem proliferado consideravelmente na sociedade contemporânea, constituindo-se a própria condição de seu desenvolvimento. "A vida moderna, sobretudo a urbana, é toda mediada por organizações [...] Enfim, onde há processos de trabalho - pessoas trabalhando de maneira sistemática e organizada - ali há administradores". (TEIXEIRA JÚNIOR, 2015, p. 122).

Pode-se observar ainda que, na Engenharia Civil, foram ofertados 132 cursos em 2004 e 528 no ano de 2013, um crescimento de $75 \%$ no período. Houve significativa participação da esfera privada, com a oferta de 77 cursos em 2004 e de 401 em 2013, evidenciando uma evolução de $80,8 \%$, enquanto, na esfera pública, no mesmo período, o aumento foi de 56,7\%. Esses dados evidenciam que esse curso, entre os quatro pesquisados, foi o que mais cresceu no país. De acordo com Oliveira et al. (2013), a formação em Engenharia Civil denuncia um expressivo crescimento não somente quando analisada de maneira isolada, mas também quando comparada com a de outros cursos. Ainda segundo os autores, uma possível

\footnotetext{
[...] explicação pode ser o fato de a Engenharia Civil estar "em alta" nestes últimos anos, determinando a abertura de cursos novos e a ampliação de vagas nos cursos existentes, aumentando o número de matriculados, os quais ainda não tiveram tempo suficiente para concluir curso. (OLIVEIRA et al., 2013 p. 27)
}

Dos quatro cursos investigados, o de Enfermagem foi o que teve crescimento mais equilibrado no período 2004-2013 em termos percentuais, tanto no que tange ao total $(55,1 \%)$, quanto em termos de categoria administrativa das IES - privada e pública - 54,7\% e $56,8 \%$ respectivamente. Tal equilíbrio pode ser justificado, em grande parte, pelas políticas de educação superior formuladas para os dois setores. $\mathrm{Na}$ esfera privada, foram implantados, por exemplo, o Fundo de Financiamento ao Estudante do Ensino Superior, em 2001, e o Programa Universidade para Todos - ProUni, em 2005, o que contribuiu para a expansão do setor. $\mathrm{Na}$ esfera pública, foi instituído o Programa de Apoio a Planos de Reestruturação e Expansão das Universidades Federais/Reuni (BRASIL, 2007a). "Supõe-se que a evolução dos cursos no setor público federal esteja relacionada ao processo de expansão das universidades federais (criação de universidades e interiorização de algumas já consolidadas)" (SEIFFERT; ABENSUR, 2012, p. 233).

No caso do curso de Pedagogia, ocorreu a menor variação percentual $(12,2 \%)$ na série histórica 2004-2012, quando os cursos passaram de 1.437 para 1.637. Na rede privada, o percentual também foi o menos expressivo, enquanto, no setor público, houve um 
decréscimo (-7,5\%). Esse foi identificado nas IES estaduais, visto que eram 466 em 2004 e 345 em 2013, implicando variação de -35,1\%. Não obstante, ao mesmo tempo, as federais avançaram 18,2\%, e as municipais, 51,9\%. A procura cada vez menor por esse curso no Brasil se justifica "seja por questões mercantilistas, seja por questões de desvalorização dos cursos de licenciatura e da investigação educacional, pedagógica e didática" (GATTI, 2014, p. 36).

Apesar desse processo de expansão da educação superior, é indispensável destacar que o Brasil, historicamente, mantém a taxa de escolaridade líquida muito aquém dos países desenvolvidos e da maioria dos latino-americanos. O gargalo imposto é resultado, entre outros aspectos, da escolaridade líquida do ensino médio, no qual pouco mais de 50\% dos jovens estão matriculados (CARVALHO, 2015).

Nesse cenário, tornam-se claras as marcas expansionista e privatista da educação superior brasileira, fortemente estimuladas pelo governo Fernando Henrique Cardoso, em seus dois mandatos (19951998 e 1999-2002). Na administração seguinte - Luís Inácio Lula da Silva - considerando-se também seus dois mandatos (2003-2006 e 2007-2010), a política de expansão do setor privado foi incrementada. Todavia, esse segundo governo inaugurou uma política de ampliação do setor público por meio do Reuni.

Contudo, a efetividade das duas políticas, de expansão privada e do Reuni, precisa ser problematizada, uma vez que as camadas de baixa renda que aspiram à educação superior não necessitam apenas de gratuidade integral ou parcial para estudar. Demandam também condições para que as instituições públicas, como ferramentas da função redistributiva da União, possam equalizar oportunidades como transporte, moradia estudantil, alimentação subsidiada, assistência médica disponível nos hospitais universitários e bolsas de trabalho e pesquisa (CARVALHO, 2015).

No caso dos cursos pesquisados, constata-se que, embora a maior parcela das matrículas tenha se materializado pela iniciativa privada, é ainda no setor público, sobretudo nas universidades, que são ofertados cursos de alta qualidade, definida a partir do conceito Enade. Cabe aqui reiterar ressalvas sobre o que se denomina "conceito oficial de qualidade", bem como a respeito dos níveis dessa qualidade na escala do Sinaes (1 a 5).

Os percentuais de conceitos positivos, entre 3 e 5 , já mostrados no Gráfico 1, no qual se observou que, na ACG, 98,8\% dos cursos oferecidos obtiveram esses conceitos, opõem-se à obtenção de baixos percentuais de qualidade (indicadores 1 e 2). Isso quando se leva em 
conta que, para essa avaliação, a política do Sinaes define o 3 como satisfatório, ou seja, como indicador de qualidade. Ao mesmo tempo, $85,5 \%$ e $67,2 \%$ alcançaram, respectivamente, no CPC e no Enade o mesmo intervalo de conceitos. Na ACG, apenas 1,2\% receberam conceitos entre 1 e 2 , o que dificulta lidar com a tese sobre qualidade precária da educação superior no Brasil. Por outro lado, há que se considerar que "os cursos de baixa qualidade não sofrem sanções do Estado, e, portanto, não há pressão para que melhorem seu nível" (TEIXEIRA JÚNIOR, 2015, p. 113).

O quadro sobre os principais indicadores de qualidade do Sinaes e seus desdobramentos na expansão e no acesso a cursos de educação superior pode ser ampliado com a análise dos cursos classificados como de alta qualidade, segundo a métrica do Enade. Reforça-se que os cursos discutidos neste artigo são aqueles que obtiveram, de forma reiterada, os conceitos Enade 4 e/ou 5 desde 2004. A seguir, será focalizada, à luz do conceito Enade, a expansão dos quatro cursos selecionados.

\section{a) Os cursos de Administração}

Os dados da Tabela 2 mostram a tênue evolução que ocorreu entre os cursos de Administração com conceitos Enade 4 e/ou 5. Do total, apenas 16,5\% em 2006; 16,6\% em 2009; e 19,5\% em 2012 registraram esses conceitos, percentuais bastante assimétricos em relação à expansão dos cursos entre 2006 e 2012. Tal assimetria é mais evidente quando são considerados os ciclos avaliativos de 2006 e 2009, quando havia 182 cursos de Administração no país e houve somente $0,1 \%$ de aumento dos cursos avaliados como de alta qualidade no mesmo período.

TABELA 2 - Distribuição dos conceitos Enade dos cursos de Administração (2006, 2009, 2012)

\begin{tabular}{c|c|c|c|c|c|c}
\hline \multirow{2}{*}{$\begin{array}{c}\text { Escala } \\
\text { do Enade }\end{array}$} & \multicolumn{2}{|c|}{2006} & \multicolumn{2}{c|}{2009} & \multicolumn{2}{c}{2012} \\
\cline { 2 - 7 } & N & $\%$ & N & $\%$ & N & $\%$ \\
\hline 1 e 2 & 363 & 32,0 & 524 & 39,8 & 427 & 34,9 \\
\hline 3 & 583 & 51,5 & 573 & 43,6 & 558 & 45,6 \\
\hline 4 e 5 & 187 & 16,5 & 218 & 16,6 & 238 & 19,5 \\
\hline Total geral & 1.133 & 100,0 & 1.315 & 100,0 & 1.223 & 100,0 \\
\hline
\end{tabular}

Fonte: Planilha com resultados do Enade fornecida pela CGCQES/Daes em 2014 . $^{4}$ 
Nos cursos de Administração que mantiveram os conceitos 4 e/ou 5 na série, a realidade apresenta-se diferente. Ao se considerar a distribuição dos cursos classificados como de alta qualidade por categoria administrativa, constata-se no universo deles (76), que $61,8 \%$ se vinculavam à esfera pública, conforme evidenciam os dados mostrados na Tabela 3. Quanto à organização acadêmica, 69,7\% eram ofertados por universidades, a maioria em IES públicas (59\%). As privadas participaram com 29 cursos $(38,2 \%)$, destacando-se os das faculdades $(58,6 \%)$.

TABELA 3 - Distribuição dos cursos de Administração com Enade 4 ou 5, por organização acadêmica e categoria administrativa $(2005,2008,2011)$

\begin{tabular}{c|c|c|c|c|c|c|c|c}
\hline \multirow{2}{*}{$\begin{array}{c}\text { Organização } \\
\text { acadêmica }\end{array}$} & \multicolumn{2}{|c|}{ Estadual } & \multicolumn{2}{c|}{ Federal } & \multicolumn{2}{c|}{ Privada } & \multicolumn{2}{c}{ Total geral } \\
\cline { 2 - 9 } & N & $\%$ & N & $\%$ & N & $\%$ & N & $\%$ \\
\hline Centro universitário & 0 & 0,0 & 2 & 6,9 & 4 & 13,8 & 6 & 7,9 \\
\hline Faculdade & 0 & 0,0 & 0 & 0,0 & 17 & 58,6 & 17 & 22,4 \\
\hline Universidade & 18 & 100,0 & 27 & 93,1 & 8 & 27,6 & 53 & 69,7 \\
\hline Total geral & 18 & 100,0 & $\mathbf{2 9}$ & 100,0 & 29 & 100,0 & 76 & 100,0 \\
\hline
\end{tabular}

Fonte: Planilha com resultados do Enade fornecida pela CGCOES/Daes em $2014 .^{5}$

A concentração de aproximadamente dois terços desses cursos de alta qualidade em universidades - em sua maioria, públicas - evidencia uma tendência da expansão da educação superior há décadas no país: a maior presença de cursos com melhor desempenho em IES cuja missão é articular ensino, pesquisa e extensão. Para Teixeira Júnior (2015), em termos práticos, isso resulta na

[...] separação entre aqueles que produzem conhecimento e aqueles que apenas o transmitem. A educação superior no nível da graduação - em especial, a graduação em Administração - transforma-se, então, num espaço de transmissão de pacotes de conhecimento, para salas de aulas lotadas, muito conveniente para IES que operam sob uma lógica prioritariamente empresarial. (TEIXIERA JÚNIOR, 2015 p. 109)

Essa tendência histórica de expansão da educação superior brasileira revela a necessidade do permanente estudo do Sinaes, com foco, sobretudo, na discussão da qualidade por ele aferida. O esforço precisa ser empreendido de forma que esse sistema mostre condições efetivas para garantir os padrões de qualidade necessários ao alcance dos propósitos mais amplos desse nível educacional no país. 


\section{b) Os cursos de Engenharia Civil}

Pode-se observar na Tabela 4, a seguir, que os cursos de Engenharia Civil apresentaram evolução na obtenção dos conceitos Enade 4 e/ou 5 no decorrer da série. Todavia, esse progresso foi pouco expressivo, visto que a média do período 2005-2011 chegou a $22,3 \%$, enquanto a relativa a 1 e 2 , no mesmo período, foi de $43,3 \%$, praticamente o dobro.

TABELA 4 - Distribuição dos conceitos Enade dos cursos de

Engenharia Civil (2005, 2008, 2011)

\begin{tabular}{c|c|c|c|c|c|c}
\hline \multirow{2}{*}{$\begin{array}{c}\text { Escala } \\
\text { do Enade }\end{array}$} & \multicolumn{2}{|c|}{2005} & \multicolumn{2}{c|}{2008} & \multicolumn{2}{c}{2011} \\
\cline { 2 - 7 } & $\mathbf{N}$ & $\%$ & $\mathbf{N}$ & $\%$ & $\mathbf{N}$ & $\%$ \\
\hline $\mathbf{1}$ e 2 & 62 & 47,3 & 78 & 47,9 & 51 & 34,7 \\
\hline $\mathbf{3}$ & 44 & 33,6 & 49 & 30,1 & 58 & 39,5 \\
\hline $\mathbf{4}$ e 5 & $\mathbf{2 5}$ & $\mathbf{1 9 , 1}$ & $\mathbf{3 6}$ & $\mathbf{2 2 , 1}$ & $\mathbf{3 8}$ & $\mathbf{2 5 , 9}$ \\
\hline Total Geral & $\mathbf{1 3 1}$ & 100,0 & $\mathbf{1 6 3}$ & 100,0 & $\mathbf{1 4 7}$ & 100,0 \\
\hline
\end{tabular}

Fonte: Planilha com resultados do Enade fornecida pela CGCQES/Daes em $2014 .^{6}$

Os dados da mesma tabela mostram que a maior parte dos cursos avaliados obteve o conceito satisfatório 3 (39,5\%), definido na política do Sinaes como referencial mínimo de qualidade para fins regulatórios. Ainda que esse percentual seja muito próximo daquele alcançado pelos cursos de Engenharia Civil que receberam notas insatisfatórias, ele diz respeito ao que é definido como adequado para a qualidade da educação superior. Esse fato comprova que "o Enade termina sendo privilegiado, uma vez que ele é a principal fonte das variáveis consideradas na construção do CPC e também do IGC, havendo nítido esvaziamento da relevância dada à autoavaliação institucional" (WEBER, 2010, p. 1.264).

Dos cursos de Engenharia Civil, apenas 11 conservaram um desempenho de alta qualidade, como se constata na Tabela 5.

TABELA 5 - Distribuição dos cursos com Enade 4 ou 5, por organização acadêmica e categoria administrativa $(2005,2008,2011)$

\begin{tabular}{c|c|c}
\hline \multirow{2}{*}{ Organização acadêmica } & \multicolumn{2}{|c}{ Categoria administrativa } \\
\cline { 2 - 3 } & Pública & Privada \\
\hline Universidade & 11 & 0 \\
\hline Centros universitários & 0 & 0 \\
\hline Faculdades & 0 & 0 \\
\hline
\end{tabular}

Fonte: Planilha com resultados do Enade fornecida pela CGCQES/Daes em 2014 . $^{7}$ 
Cabe ressaltar que, entre os cursos selecionados para pesquisa e que, reiteradamente, obtiveram conceito 4 e/ou 5, o de Engenharia Civil é o único que está restrito às universidades públicas, perspectiva que se alinha àquela já observada em relação aos cursos de Administração. Tudo indica que as universidades públicas têm conseguido garantir um destaque na oferta desses cursos, uma vez que apresentam um bom perfil organizacional. Tal perfil se traduz na garantia de condições capazes de propiciar o desenvolvimento de suas atividades de ensino, pesquisa e extensão, bem como o cumprimento de sua missão no que tange à contribuição para o desenvolvimento nacional e regional.

\section{c) Os cursos de Enfermagem}

Diferentemente dos cursos de Administração e Engenharia Civil, os de Enfermagem, como mostra a Tabela 6, apresentaram uma oscilação com expressiva redução na obtenção dos conceitos Enade 4 e/ ou 5 na série. Chama atenção a significativa queda do número de cursos nas faixas de conceitos 4 e/ ou 5 quando se comparam os três ciclos 2004, 2007 e 2010 -, o que se faz notar mais do primeiro para o segundo.

TABELA 6 - Distribuição dos conceitos Enade dos cursos de Enfermagem $(2004,2007,2010)$

\begin{tabular}{c|c|c|c|c|c|c}
\hline \multirow{2}{*}{$\begin{array}{c}\text { Escala } \\
\text { do nade }\end{array}$} & \multicolumn{2}{|c|}{2004} & \multicolumn{2}{c|}{2007} & \multicolumn{2}{c}{2010} \\
\cline { 2 - 7 } & $\mathbf{N}$ & $\%$ & $\mathbf{N}$ & $\%$ & $\mathbf{N}$ & $\%$ \\
\hline $\mathbf{1}$ e 2 & 10 & 5,5 & 159 & 47,0 & 228 & 43,2 \\
\hline $\mathbf{3}$ & 75 & 41,4 & 128 & 37,9 & 195 & 36,9 \\
\hline $\mathbf{4}$ e 5 & $\mathbf{9 6}$ & $\mathbf{5 3 , 0}$ & $\mathbf{5 1}$ & $\mathbf{1 5 , 1}$ & $\mathbf{1 0 5}$ & $\mathbf{1 9 , 9}$ \\
\hline Total geral & $\mathbf{1 8 1}$ & 100,0 & $\mathbf{3 3 8}$ & 100,0 & $\mathbf{5 2 8}$ & 100,0 \\
\hline
\end{tabular}

Fonte: Planilha com resultados do Enade fornecida pela CGCQES/Daes em $2014 .^{8}$

Correlacionando-se os números relativos ao crescimento da quantidade de cursos de Enfermagem com os conceitos Enade por eles obtidos, verifica-se uma contradição: a grande expansão desses cursos, nos três ciclos avaliativos, não foi acompanhada pelo aumento proporcional dos mesmos cursos mais bem-avaliados no exame.

Nessa perspectiva, a política de expansão apresenta um descompasso entre quantidade e qualidade, uma vez que o incremento de novos cursos de Enfermagem não acompanhou o quantitativo de cursos com avaliação considerada de excelência, correspondente aos conceitos 4 ou 5 no Enade. (ABDALLA et al. 2016, p. 631) 
Somente 35 cursos de Enfermagem mantiveram os conceitos 4 e/ ou 5 durante os ciclos avaliativos pesquisados. Ao se comparar o desempenho entre as IES públicas e privadas, conforme a Tabela 7 traz, evidencia-se que as primeiras $(91,4 \%$ ) têm significativa vantagem no conceito Enade em relação às segundas.

TABELA 7 - Distribuição dos cursos de Enfermagem com Enade 4 ou 5 , por organização acadêmica e categoria administrativa $(2004,2007,2010)$

\begin{tabular}{|c|c|c|c|c|c|c|}
\hline \multirow{3}{*}{$\begin{array}{c}\text { Organização } \\
\text { acadêmica }\end{array}$} & \multicolumn{4}{|c|}{ Categoria administrativa } & \multirow{2}{*}{\multicolumn{2}{|c|}{ Total geral }} \\
\hline & \multicolumn{2}{|c|}{ Público } & \multicolumn{2}{|c|}{ Privado } & & \\
\hline & N & $\%$ & N & $\%$ & N & $\%$ \\
\hline Faculdade & 2 & 6,3 & 2 & 66,7 & 4 & 11,4 \\
\hline Universidade & 30 & 93,8 & 1 & 33,3 & 31 & 88,6 \\
\hline Total geral & 32 & 100,0 & 3 & 100,0 & 35 & 100,0 \\
\hline $\begin{array}{l}\text { Total geral (\%) } \\
\text { por dependência } \\
\text { administrativa }\end{array}$ & 91,4 & - & 8,6 & - & 100,0 & - \\
\hline
\end{tabular}

Fonte: Planilha com resultados do Enade fornecida pela CGCQES/Daes em $2014 .^{9}$

A política do Sinaes prevê que os resultados obtidos pela prova do Enade sejam discutidos de maneira articulada com outros resultados da avaliação da IES. Em decorrência disso, quando os dados da Tabela 7 indicam que 88,6\% dos cursos de Enfermagem que alcançaram as melhores notas são ofertados por universidades, cuja maioria (30, ou 96,8\%) é pública, não deixam de tensionar o campo da avaliação nesse tipo de IES. Isso porque estudos como os realizados por Lima, Cunha e Silva (2013) demonstram que, igualmente, nas universidades os dados coletados por meio dos instrumentos avaliativos do Sinaes também tendem a ser trabalhados de modo fragmentado. Nessa perspectiva, os autores afirmam que

[...] a implementação do Sinaes nas universidades tem se tornado um conflito paradigmático. O discurso teórico sustenta uma avaliação democrática e participativa no paradigma da emancipação, por um lado, mas por outro estamos, na prática fortalecendo o viés regulatório, na medida em que priorizamos os componentes 
avaliativos que trazem resultados imediatos, como notas e índices, com possibilidades de classificação e ranqueamento. (LIMA; CUNHA; SILVA, 2013, p. 107)

\section{d) Os cursos de Pedagogia}

Por fim, os cursos de Pedagogia com conceitos 4 e/ou 5 no Enade também apresentaram discreta oscilação negativa decrescente entre o primeiro e o terceiro ciclos avaliativos, de acordo com os dados da Tabela 8, a seguir.

TABELA 8 - Distribuição dos conceitos Enade dos cursos de Pedagogia participantes dos ciclos 2005, 2008, 2011

\begin{tabular}{c|c|c|c|c|c|c}
\hline \multirow{2}{*}{$\begin{array}{c}\text { Escala } \\
\text { do Enade }\end{array}$} & \multicolumn{2}{|c|}{2005} & \multicolumn{2}{c|}{2008} & \multicolumn{2}{c}{2011} \\
\cline { 2 - 7 } & N & $\%$ & N & $\%$ & N & $\%$ \\
\hline 1 e 2 & 100 & 15,5 & 229 & 24,2 & 217 & 26,0 \\
\hline 3 & 373 & 57,8 & 441 & 46,7 & 403 & 48,2 \\
\hline 4 e 5 & 172 & 26,7 & 275 & 29,1 & 216 & 25,8 \\
\hline Total geral & 645 & 100,0 & 945 & 100,0 & 836 & 100,0 \\
\hline
\end{tabular}

Fonte: Planilha com resultados do Enade fornecida pela CGCQES/Daes em 2014. ${ }^{10}$

De forma geral, o conceito Enade no curso de Pedagogia está envolto em controvérsias que já duram algum tempo e que são motivadas, sobretudo, pelas críticas formuladas por Gatti (2014) de que esse curso vem apresentando resultados que apontam para sua baixa qualidade. Em relação à questão, a Meta 13 do Plano Nacional de Educação 2014-2024, relativa à elevação da qualidade da educação superior, conta com a estratégia 13.4, destinada a "promover a melhoria da qualidade dos cursos de Pedagogia e licenciaturas por meio da aplicação de instrumento próprio de avaliação aprovado pela [...] Conaes, integrando-os às demandas e às necessidades das redes de educação básica" (BRASIL, 2014).

Pode ser observado na Tabela 9 que, dos 48 cursos de Pedagogia, que, na série estudada, mantiveram o desempenho de alta qualidade, $54,2 \%$ deles, correspondendo a 26 , também se vinculavam às universidades públicas. 
TABELA 9 - Distribuição dos cursos de Pedagogia com Enade 4 ou 5 por organização acadêmica e categoria administrativa $(2004,2007,2010)$

\begin{tabular}{c|c|c|c|c|c|c}
\hline \multirow{2}{*}{$\begin{array}{c}\text { Organização } \\
\text { acadêmica }\end{array}$} & \multicolumn{4}{|c|}{ Categoria administrativa } & \multicolumn{2}{c}{ Total geral } \\
\cline { 2 - 6 } & N & $\%$ & N & $\%$ & N & $\%$ \\
\hline Centro universitário & 0 & 0 & 3 & 13,6 & 3 & 6,25 \\
\hline Faculdade & 0 & 0 & 3 & 13,6 & 3 & 6,25 \\
\hline Universidade & 26 & 100 & 16 & 72,7 & 42 & 87,5 \\
\hline $\begin{array}{c}\text { Total geral } \\
\text { Total \% por } \\
\text { dependência } \\
\text { administrativa }\end{array}$ & 26 & 100 & 22 & 100,0 & 48 & 100,0 \\
\hline
\end{tabular}

Fonte: Planilha com resultados do Enade fornecidas pela CGCOES/Daes em $2014 .^{11}$

Os dados da tabela anterior indicam que 72,7\% (42 de um total de 48) dos cursos estavam em universidades, fato que pode se associado à qualidade da formação ofertada por esse tipo de instituição, em contraste com as faculdades e os próprios centros universitários, dois tipos de estabelecimentos majoritariamente vinculados ao setor privado.

Os números analisados até aqui permitem inferir-se que as bases epistemológicas do que se entende por avaliação de qualidade ainda estão alicerçadas na política do Sinaes. Entretanto, como assinala Marx (1985, p. 83), "a legislação, tanto política, como civil, apenas enuncia, verbaliza as exigências das relações". De tal modo, como discutido ao longo deste artigo, a percepção acadêmica e social do que é reconhecido como avaliação de qualidade não pertence ao Estado: é enunciada por ele e verbalizada na lei; se o governo adota ou não o procedimento que verbalizou, isso não desvirtua a compreensão social daquele objeto ou conceito. Sabe-se que, no caminho entre a lei e seus inúmeros regulamentos, diversos atores entram em cena e buscam fazer valer sua percepção do objeto regulado.

Por outro lado, os mesmos dados suscitam a expectativa de que o conceito Enade - em relação aos cursos avaliados ou a outros que venham a ser investigados - possa ser discutido sob outras perspectivas de análise. Isso precisa ocorrer, fundamentalmente, em 
relação ao que é entendido como qualidade da educação superior do país, notadamente quando associada àquele conceito. Afinal, a avaliação é legitimada mediante a expectativa de que, em decorrência dos diagnósticos feitos pela avaliação, "alguma coisa venha a acontecer" (BELLONI, 1989, p. 86-87).

De fato, o panorama analisado neste trabalho permite refletir se o reduzido percentual de cursos considerados de excelência, na perspectiva do governo (Inep, 2015a, 2016), teria o potencial de revelar a fragilidade da função redistributiva da União em matéria de disseminar a educação de qualidade no Brasil.

Nunca é demais indagar a respeito dos sujeitos, dos interesses e das forças subjacentes às políticas de avaliação. Nessa lógica, Dias Sobrinho (2003) alerta que, em geral, a avaliação realizada pelo Estado privilegia procedimentos contrários a uma prática formativa. Ao contrário, estimula a "hierarquização institucional com base em resultados de testes de rendimentos e quantificação de produtos, (re) credenciamento de cursos [...]" (DIAS SOBRINHO, 2003, p. 59).

Em outra direção, é preciso lembrar que, perpassada por questões técnicas e sentidos éticos e políticos, a avaliação sempre está inserida em núcleos de poder, ao mesmo tempo em que se mostra atravessada por contradições. Como diz o autor, não é possível compreendê-la em abstrato, visto que se trata de uma produção social e histórica e que, exatamente por isso, mantém relações interativas com outras produções de natureza igualmente histórica e social. Sendo assim, a avaliação tanto pode induzir transformações, quanto pode ser transformada.

\section{CONSIDERACְÕES FINAIS}

$\mathrm{Na}$ discussão feita neste artigo, a recorrência de determinadas ideias, que dominaram as seções deste trabalho, impôs a delimitação das considerações finais em duas questões centrais. Uma delas é de caráter mais amplo e se refere à relação entre a métrica estabelecida pelo Estado - conceito Enade - e os resultados obtidos pelos cursos eleitos para estudo, considerando-se os três ciclos avaliativos pesquisados.

O cotejamento dos dados levantados na pesquisa permitiu concluir-se que, para além dos termos adjetivados e adotados pelo Inep nos descritores dos conceitos 4 e 5 do Enade, um curso de alta qualidade é ofertado, na maioria dos casos analisados, em ambiente acadêmico que apresenta maior sintonia com os indicadores do Sinaes. Esse quadro é configurado também a partir de números concernentes a três fontes - Avalies, ACG e Capes. 
Partindo-se do princípio de que uma análise é, ao mesmo tempo, explicativa e interpretativa, os mesmos dados possibilitam insistir-se na tese de que a métrica da qualidade satisfatória para o Estado é a escala entre 3 e 5. Todavia, os níveis 4 e 5 evidenciam acesso mais privilegiado aos bônus regulatórios, por exemplo, e são merecedores de maior prestígio, oferecendo a ideia de que seus egressos teriam capital escolar, cultural e econômico capaz de proporcionar acesso a escalões superiores no aparelho do Estado, na sociedade e no mercado.

Analisando-se estudos sobre a correlação entre nível educacional e riqueza, destaca-se o entendimento de Medeiros (2003, p. 11), que investigou em tese doutoral se "a escolaridade média dos trabalhadores seria capaz de mover um grande volume da população ao estrato rico". Na conclusão de seu estudo, o autor assevera que, mesmo em um cenário onde todos eles "possuíssem educação de nível superior, o movimento de pessoas do estrato não rico ao estrato rico seria extremamente reduzido" (MEDEIROS, 2003, p. 12). Para o autor, a educação não é o único elemento que conta na ascensão às camadas sociais mais favorecidas, pois, ainda que não tivessem curso superior, $40 \%$ dos cerca de 600 mil trabalhadores no topo da pirâmide de renda, ou 1\%, continuariam ricos.

Por outro lado, a associação entre meritocracia e diploma já foi desmitificada por muitos autores, encontrando-se excelente abordagem em Barbosa (1999), ao enfatizar que não há no Brasil um "sistema meritocrático formal” (BARBOSA, 1999, p. 69), com vistas à ascensão social baseada em desempenho; os critérios são outros, como relações pessoais e consanguíneas, poder econômico e político.

Com efeito, serão necessárias mais pesquisas até que se entenda o que, de fato, significam cursos com conceitos 4/5 no Enade ou em outros indicadores oficiais. Esse nível de compreensão é indispensável no sentido de perceber se tais conceitos efetivamente refletem desempenho do estudante ou apenas "sustentam modelos hierárquicos de divisão da sociedade em classes nos quais a assimetria entre as classes permite relações de exploração, dominação e subordinação entre elas" (MEDEIROS, 2003, p. 59). Nessa linha de raciocínio, indaga-se: será mesmo descabido atribuir aos cursos desse nicho de qualidade uma forma de responsabilidade pela manutenção da estratificação social? Observe-se que o ingresso nos cursos de alta qualidade, o qual, em tese, ocorre com "igualdade de condições para o acesso e a permanência" (art. 206 da CF/88), é uma realidade dissociada do que se tem aprendido sobre a "real meritocracia", como ensina Barbosa (1999).

Ainda que a título de sinalização provisória, é possível encerrar a reflexão proposta neste artigo invocando a tese de Bourdieu (1990, 
p. 158) de que "as representações dos agentes variam segundo sua posição e (os interesses e que estão sendo associados a ela) e segundo seu habitus". No âmbito da discussão aqui feita, essa tese se estende à forma como as percepções dos diferentes atores se manifestam a respeito da métrica do Enade.

É razoável compreender que cursos com notas 4 e 5 são de fato uma fiel métrica da qualidade educacional em si. Todavia, há duas questões anteriores: sobre qual qualidade se está tratando e a quais arenas ela satisfaz? Também pode ser uma eficaz métrica da classificação de indivíduos e dos estratos sociais com poder de comando, detentores de capital cultural e econômico (BOURDIEU, 1990). De toda sorte, cursos nesse nível de qualidade constituem um valor apreciável nos meios governamental, social e acadêmico.

Por fim, vale lembrar que, do ponto de vista constitucional, no Brasil a iniciativa privada de ensino é livre para atuar, sob a condição de manter a qualidade. A questão é: como fazer com que as IES cumpram tal dispositivo: ministrar cursos nos níveis aceitáveis, à luz das diretrizes gerais (avaliativas e regulatórias) emanadas pela União, e que, ao mesmo tempo, satisfaçam às diversas concepções de qualidade?

\section{REFERÊNCIAS}

ABDALLA, I. G.; MORENO, L. R.; ABENSUR, P.; SEIFFERT, O. M. L. B.; LIMEIRA, P. O padrão oficial de qualidade dos cursos de Enfermagem: uma análise dos resultados do Enade (2004, 2007 e 2010) e da associação com outros indicadores do Sinaes. In: SEMINÁRIO NACIONAL UNIVERSITAS/BR, 24., Maringá, 2016. Anais... Maringá/ PR: UEM, 2016, p. 611-634.

BARBOSA, L. Meritocracia à brasileira. O que é desempenho no Brasil. Revista Del Clad Reforma y Democracia, Caracas-VEN, v. 1, p. 1, 1999.

BELLONI, I. Entrevista. Perspectiva. CED, Florianópolis, v. 6, n. 12, p. 96-111, jan./jun. 1989. BOURDIEU, P. Coisas ditas. São Paulo: Brasiliense, 1990.

BRASIL. Constituição (1988). Constituição da República Federativa do Brasil. Diário Oficial [da] República Federativa do Brasil. Brasília-DF, Seção I, p. 1, 5 out. 1988

Lei n ${ }^{\circ}$ 9.394, de 20 de dezembro de 1996. Estabelece as diretrizes e bases da educação nacional. Diário Oficial [da] República Federativa do Brasil. Brasília-DF, Seção I, p. 27.833-27.841, 23 dez. 1996.

. Lei no 10.172, de 9 de janeiro de 2001. Aprova o Plano Nacional de Educação e dá outras providências. Diário Oficial [da] República Federativa do Brasil. Brasília-DF, n. 7, Seção 1, p. 177, 10 jan. 2001.

. Lei n ${ }^{\circ}$ 10.861, de 14 de abril de 2004. Institui o Sistema Nacional de Avaliação da Educação Superior (SINAES) e dá outras providências. Diário Oficial [da] República Federativa do Brasil. Brasília-DF, 15 abr. 2004, n. 72, Seção 1, p.3-4.

. Lei no 13.005, de 25 de junho de 2014. Aprova o Plano Nacional de Educação - 
PNE e dá outras providências. Diário Oficial [da] República Federativa União. BrasíliaDF, Edição Extra. Seção 1, p. 1, 26 jun. 2014.

. Medida Provisória no 147, de 15 de dezembro 2003. Institui o Sistema Nacional de Avaliação e Progresso do Ensino Superior e dispõe sobre a avaliação do ensino superior. Diário Oficial [da] República Federativa do Brasil. Brasília-DF, 16 dez. 2003.

Decreto $\mathrm{n}^{\circ}$ 5.773, de 9 de maio de 2006. Dispõe sobre o exercício das funções de regulação, supervisor e avaliação de instituições de educação superior e cursos superiores de graduação e sequenciais do sistema federal de ensino. Diário Oficial [da] República Federativa do Brasil. Brasília-DF, n.88, Seção 1, p. 6, 10 maio 2006.

Decreto $n^{\circ}$ 6.096, de 24 de abril de 2007. Institui o Programa de Apoio a Planos de Reestruturação e Expansão das Universidades Federais - REUNI. 2007a. Diário Oficial [da] República Federativa do Brasil. Brasília-DF, 25 abr. 2007.

. Ministério da Educação. Portaria Normativa n. 40 de 12 de dezembro de 2007. Institui o e-MEC, sistema eletrônico de fluxo de trabalho e gerenciamento de informações relativas aos processos de regulação da educação superior no sistema federal de educação. 2007b. Diário Oficial [da] República Federativa do Brasil. 13 dez. 2007.

Portaria Normativa $\mathrm{n}^{\circ} 12$, de 08 de setembro de 2008. Institui o Índice Geral de Cursos da Instituição de Educação Superior. 2008a. Diário Oficial [da] República Federativa do Brasil. Brasília-DF, Seção I, 8 set. 2008.

. Portaria Normativa n ${ }^{\circ}$, de 07 de agosto de 2008. Regulamenta a aplicação do conceito preliminar de cursos superiores - CPC, para fins dos processos de renovação de reconhecimento respectivos, no âmbito do ciclo avaliativo do SINAES instaurado pela Portaria Normativa n ${ }^{\circ}$, de 2007. 2008b. Diário Oficial [da] República Federativa do Brasil. Brasília-DF, Seção I, p. 19, 6 ago. 2008.

. Conselho Nacional de Educação. Parecer CNE/CES n 471/2007. Relator Paulo Monteiro Vieira Braga Barone. Recurso contra decisão do Parecer CNE/CP n ${ }^{\circ}$ 1/2007, Recurso contra decisão do Parecer CNE/CES no 471/2005, referente à renovação do reconhecimento do curso de Direito, bacharelado, ministrado pela Universidade do Oeste Paulista, com sede na cidade de Presidente Prudente, no Estado de São Paulo. 2007b. Disponível em <http://portal.mec.gov.br> Acesso em 12 jul. 2016.

. Parecer CNE/CES no 37/2010. Relator Edson de Oliveira Nunes. Recurso da Faculdade Anísio Teixeira de Feira de Santana contra ato da SESu/MEC que, por meio da Portaria SESu/MEC no 886/2009 , indeferiu autorização do curso de Nutrição, bacharelado. 2010. Disponível em <http://portal.mec.gov.br>. Acesso em 12 jul. 2016.

CARvalho, C. H. A. Política de Expansão da educação Superior nos Governos Democráticos Brasileiros (1995-2013). In: SOUSA, J. V. Expansão e Avaliação da educação superior brasileira: formatos, desafios e novas configurações. Belo Horizonte: Fino Traço/Faculdade de Educação da Universidade de Brasília, 2015. p. 73-93.

CHIZZOT'TI, A. Pesquisa Qualitativa em Ciências Humanas e Sociais. Petrópolis-RJ: Vozes, 2006.

COMISSÃO ESPECIAL DE AVALIAÇÃO - CEA. Sistema Nacional de Avaliação da Educação Superior (Sinaes): bases para uma proposta da educação superior. Brasília: MEC, 2003.

DIAS SOBRINHO, J. Universidade e avaliação: entre a ética e o mercado. Florianópolis: Insular, 2002. 
Avaliação: políticas educacionais e reformas da educação superior. São Paulo: Cortez, 2003.

Educação superior: bem público, equidade e democratização. Avaliação. Campinas; Sorocaba-SP, v. 18, p. 107-126, 2013.

FOUCAULT, M. Microfísica do poder. Organização e tradução de Roberto Machado. Rio de Janeiro: Edições Graal, 1979.

GATTI, B. Formação inicial de professores para a educação básica: pesquisas e políticas educacionais. Estudos em Avaliação Educacional, São Paulo: Fundação Carlos Chagas, v. 25, n. 57, p. 24-54, jan./abr. 2014.

GIOLO, J. "SINAES” intermitentes. Avaliação, Campinas; Sorocaba-SP, v. 13, n. 3, p. 851 856, nov. 2008.

GRIBOSKI, C.; FERNANDES, I. R. Avaliação da educação superior no Brasil: como avançar sem desqualificar. In: MANCEBO, D.; BITTAR, M.; CHAVES, V. L. J. (Orgs). Educação superior: expansão e reformas educativas. Maringá: EdUEM, 2012. p. 99-125.

INSTITUTO NACIONAL DE ESTUDOS E PESQUISAS EDUCACIONAIS ANÍSIO TEIXEIRA - INEP. Fórmulas para a atribuição dos conceitos das instituições _ ENADE. Brasília: Inep, 2007. Disponível em <http://enadeies.inep.gov.br/ enadeResultado/pdfs/conceito_enade_nota_tecnica_2007.pdf>. Acesso em: 18 jul. 2016.

Cálculo do Conceito Enade. Brasília: Inep, 2010. Disponível em: <http:// download.inep.gov.br/educacao_superior/enade/notas_tecnicas/2010/nota_tecnica_ cpc_05092011.pdf>. Acesso em: 18 jul. 2016.

LIMA, E. G. S; CUNHA, F. L. J.; SILVA, J. S. O. Sistema Nacional de Avaliação da Educação Superior (Sinaes). In: SOUSA. J. V. (Org.). Educação Superior: cenários, impasses e propostas. Campinas/SP: Autores Associados, 2013. p. 91-111.

LOWI, T. J. Arenas of power. New York-USA: Paradigm publishers, 2009.

MARX, K. A miséria da filosofia. Tradução de José Paulo Neto. São Paulo: Global, 1985.

MEDEIROS, M. O que faz os Ricos ricos: um estudo sobre fatores que determinam a riqueza. 2003. 261 f. Tese (Doutorado em Sociologia) - Departamento de Sociologia, Universidade de Brasília, Brasília, 2003.

NEAVE, G. R. The evaluative state reconsidered. European Journal of Education, v. 33, n. 3, p. 265-284, sep. 1998.

NUNES, E. (Org). Educação superior no Brasil: estudos, debates, controvérsias. Rio de Janeiro: Garamond, 2012.

Edson de Oliveira Nunes: depoimento [out. 2014]. Entrevistador: Ivanildo Ramos Fernandes. Rio de Janeiro: Observatório Universitário, 2014. Entrevista concedida ao Projeto 10 anos do Sinaes. Disponível em: < http://www.observatoriouniversitario.org. br/diversos.asp> Acesso em: 10 mar. 2016.

OliveirA, V. F.; ALMEIDA, N. N.; CARVAlHO, D. M.; PEREIRA, F. A. A. Um estudo sobre a expansão da formação em Engenharia no Brasil. Revista de Ensino de Engenharia, Brasília, v. 32, p. 29-44, 2013.

PEIXOTO, M. C. L.; TAVARES, M. G. M. ; ROBL, F.; FERNANDES, I. R. A disputa pela concepção de qualidade na educação superior do Brasil: outras referências. In: SEMINÁRIO NACIONAL DA REDE UNIVERSITAS/BR: Dívida Pública e Educação Superior no Brasil, 24., Maringá-PR, 18 a 20 de maio de 2016. Anais... Maringá: Universidade Estadual de Maringá, 2016. 
RISTOFF, D. I. Educação superior no Brasil - 10 anos pós-LDB: da expansão à democratização. In: BITTAR, M.; OLIVEIRA, J. F.; MOROSINI, M. (Org.). Educação Superior no Brasil: 10 anos pós-LDB. Brasília: Instituto Nacional de Estudos e Pesquisas Educacionais Anísio Teixeira, 2008.

RISTOFF, D. I.; GIOLO, J. (Org.). Educação superior brasileira 1991-2004. Brasília: Instituto de Pesquisa Educacionais Anísio Teixeira, 2006.

SEIFFERT, O. M. L. B.; ABENSUR, P. L. D. Expansão e avaliação de cursos graduação de Enfermagem no Brasil pós-LDB/1996. In: In: SOUSA. J. V. (Org.). Educação Superior: cenários, impasses e propostas. Campinas/SP: Autores Associados, 2013. p. 219-247.

SOUSA, J. V. Qualidade na educação superior: lugar e sentido na relação público-privado. Cadernos CEDES, v. 29, p. 242-256, 2009.

Educação superior no Distrito Federal: consensos, conflitos e transformações na configuração de um campo. Brasília: Faculdade de Educação/Universidade de Brasília: Líber Livro, 2013.

SOUSA, J. V; FERNANDES, I. R. Sinaes ou NeoSinaes? A avaliação da educação superior no Brasil à luz do Enade ampliado. In: SIMPÓSIO AVALIAÇÃO DA EDUCAÇÃO SUPERIOR - AVALIES. 1., Porto Alegre, 2015. Anais... Porto Alegre:RS Universidade Federal do Rio Grande do Sul - UFRGS, 17-18 set. 2015.

SOUSA, J. V; FERNANDES, I. R. Emancipação e avaliação regulatória no sistema federal de ensino. In: SEMINÁRIO NACIONAL DA REDE UNIVERSITAS/BR: Dívida Pública e Educação Superior no Brasil, 24., Maringá/PR, 18 a 20 de maio de 2016. Anais... Maringá: Universidade Estadual de Maringá, 2016.

TAVARES, M. G. M.; OLIVEIRA, M. A. A.; SEIFFERT, O. Avaliação da educação superior na revista Ensaio: avaliação e políticas públicas em educação: ênfases e tendências. Ensaio: Avaliação e Políticas Públicas em Educação, Rio de Janeiro: CESGRANRIO, v. 19, p. 233-258, 2011.

TAVARES, M. G. M.; ROTHEN, J. C.; SANTANA, A. C. M. O discurso da qualidade em periódicos internacionais e nacionais: uma análise crítica. Revista Educação em Questão, Natal-RN, v. 51, p. 251-273, 2015.

TEIXEIRA JÚNIOR, P. R. Os efeitos do SINAES no curso de Administração. 2015. 128 f. Dissertação (Mestrado em Educação) - Pontifícia Universidade Católica de Campinas, Campinas, 2015.

WEBER, S. Avaliação e regulação da educação superior: conquistas e impasses. Educação e Sociedade, Campinas-SP, v. 31, n. 113, p. 1247-1269, out.-dez. 2010.

\section{NOTAS}

${ }^{1}$ Disponível em: <http://emec.mec.gov.br>. Acesso em: 22 abr. 2016

${ }^{2}$ Disponível em: <http://painel.mec.gov.br>. Acesso em: 25 abr. 2016

${ }^{3}$ Disponíveis em: <http://portal.inep.gov.br/>. Acesso em: 6 mar. 2016.

${ }^{4}$ Disponíveis em: <http://portal.inep.gov.br/>. Acesso em: 18 mar. 2016.

${ }^{5}$ Disponíveis em: <http://portal.inep.gov.br/>. Acesso em: 18 mar. 2016.

${ }^{6}$ Disponíveis em: <http://portal.inep.gov.br/>. Acesso em: 18 mar. 2016

${ }^{7}$ Disponíveis em: < http://portal.inep.gov.br/>. Acesso em: 23 mar. 2016 
${ }^{8}$ Disponíveis em: <http://portal.inep.gov.br/>. Acesso em: 21 mar. 2016

${ }^{9}$ Disponíveis em: <http://portal.inep.gov.br/>. Acesso em: 24 mar. 2016

${ }^{10}$ Disponíveis em: < http://portal.inep.gov.br/>. Acesso em: 2 abr. 2016.

${ }^{11}$ Disponíveis em: <http://portal.inep.gov.br/>. Acesso em: 2 abr. 2016.

Submetido: 03/04/2016

Aprovado: 28/07/2016

Contato:

José Vieira De Sousa

Qnd 43 Casa 28

Taguatinga Norte $|\mathrm{DF}|$ Brasil

CEP 72.120-430 
